\title{
Genetic Variability of Pumpkin Landraces in Brazilian Amazon
}

\section{Lúcia Helena Pinheiro Martins ${ }^{1 *}$, Hiroshi Noda², Maria Teresa Gomes Lopes ${ }^{3}$, Maria Silvesnizia Paiva Mendonça1, Ayrton Luiz Urizzi Martins ${ }^{3}$}

${ }^{1}$ Núcleo de Etnoecologia da Amazônia (NETNO), Universidade Federal do Amazonas, Manaus, Brazil

${ }^{2}$ Instituto Nacional de Pesquisas da Amazônia (INPA), Manaus, Brazil

${ }^{3}$ Faculdade de Ciências Agrárias (FCA), Universidade Federal do Amazonas, Manaus, Brazil

Email: *luciahp.martins@yahoo.com.br

How to cite this paper: Martins, L.H.P., Noda, H., Lopes, M.T.G., Mendonça, M.S.P. and Martins, A.L.U. (2016) Genetic Variability of Pumpkin Landraces in Brazilian Amazon. Agricultural Sciences, 7, 822-833. http://dx.doi.org/10.4236/as.2016.712075

Received: October 4, 2016

Accepted: December 12, 2016

Published: December 15, 2016

Copyright $\odot 2016$ by authors and Scientific Research Publishing Inc. This work is licensed under the Creative Commons Attribution International License (CC BY 4.0).

http://creativecommons.org/licenses/by/4.0/

\begin{abstract}
The family farm of the Upper Solimões region has maintained the great genetic variability of the pumpkin (Cucurbita maxima Duchesne) by the in situ conservation of the landraces which are widely used as human food. The aim of this study was to estimate the current level of genetic variability of pumpkin landraces by means of estimation techniques of genetic parameters. Landraces areas samples were the family farming production units located in floodplains ecosystems of Benjamin Constant (Upper Solimões River) and Iranduba (Lower Solimões River), Amazonas. The splitplot designs were adopted at the treatments where the main plots were the five pumpkin landraces and one commercial cultivar. Each landrace was obtained six half sib families distributed in the sub-plots. Among the results of this study, it can be concluded that the genetic variation within the each landrace is greater than the genetic variation among the landraces. The qualitative morphological characteristics bring together half-sib families collected in geographically distant locations. It can be concluded that, through the estimation of genetic parameters, there is genetic variability among local cultivars collected in family farming of Benjamin Constant and Iranduba, Amazonas.
\end{abstract}

\section{Keywords}

Amazon Agriculture, Crop Genetic Variability, Cucurbita maxima Duchesne, Genetic Resource, Local Cultivars

\section{Introduction}

The pumpkin landraces (Cucurbita maxima Duchesne) are present in the regional family farm production system and the list of plants of the diet of these populations [1]. 
The pumpkin landraces can be consumed by their mature and immature fruits, flowers and leaves as vegetables, edible seeds and ripe fruit as fodder [2] [3].

In Brazil, the diversity of species Cucurbita genus, particularly C. moschata Duchesne and $C$. maxima Duchesne, is due to the important participation of family farmers throughout history. Landraces or local cultivars are traditionally cultivated from the selection practiced by those farmers over generations, seed sharing among these, besides the occurrence of genetic factors: hybridization, recombination, mutation and migration [4].

The farmers come to pick their fruits and seeds for planting the next crop [5]. This continued selection allows for a diversity of genetic resources of importance, resulting in more resilient and adapted to harsh environments materials. Cucurbitaceae are cross-pollination plants and when different varieties are grown in one same area, genetic variability may increase [6].

In the upper Amazon River (AM), Brazil, it was observed in the large family farm variability pumpkin landraces, which is widely used in food. Local cultivars are grown in small areas, for consumption in agricultural production and marketing unit in regional markets. The varieties of family agriculture are important sources of variability of germplasm characterization and require for their best knowledge. They still represent a featured action for the knowledge of genetic variability in conservation programs, use and breeding of the species.

The Cucurbita descriptors list elaborates on vegetation data (growth habit, characteristics of branches and leaves, such as color, hairiness, position, tendril) and reproductivity (characteristics of flowers, fruits and seeds, design, primary and secondary color, main design of the shell surface, buds, etc.), environmental development characteristics, health, origin, geographic distribution, domestication, uses and importance of food and nutrition, conservation, breeding, among others [2].

The aim of this study was to estimate the current level of genetic variability of local cultivars by means of estimation techniques of genetic parameters.

\section{Materials and Methods}

The areas of collection of local cultivars samples were family agriculture production units located in high floodplain ecosystems and low characterized by wetlands with white water [7], in the Benjamin Constant, Upper Solimões River and Iranduba, the Lower Solimões River, Amazon, Brazil (Figure 1).

In sampling there were adopted the procedures for outcrossing species, such as the case of pumpkin landraces, to collect material in field conditions with gametic control [8]. In general, farmers adopt the system of pumpkin perform cultivation for simultaneous production of fruit for consumption, sale and to obtain seeds for the next crop cycle, crop lands were stratified.

The experimental test was conducted at the Horticultural Experimental Station, located at Agricultural Park State Government $\left(03^{\circ} 8^{\prime} \mathrm{S}\right.$ and $60^{\circ} 01^{\prime} \mathrm{W}$ Gr with an altitude of $72 \mathrm{~m}$ above sea level) in the $A f i$ climate Koppen [9]. The soil is classified as Red-Yellow 


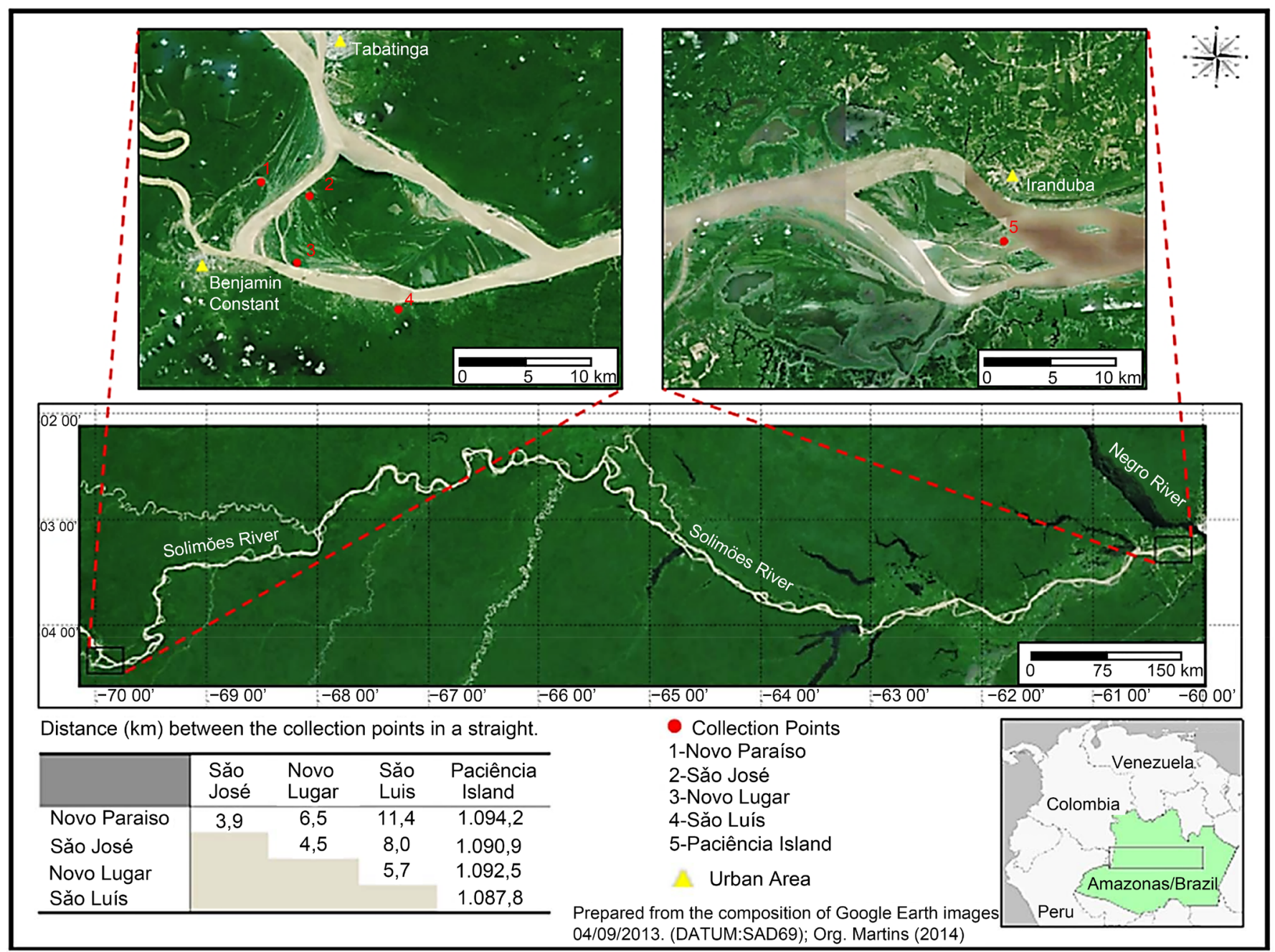

Figure 1. Study area to collect Cucurbita maxima Duchesne in agricultural production units in rural communities, Benjamin Constant and Iranduba. Amazon, Brazil. 2014.

Argisol Alic, sandy texture and low natural fertility. The experimental area is located on land with slope in the east-west direction and is divided into six terraces distributed in south-north direction. On the terraces located in the upper part of the thickness of the surface layer of sandy soil is thinner compared to the terraces located in the lower part.

The experiment was carried out in three blocks (terraces) with the history of different management. The test took the first three terraces of the Experimental Station and each block held a terrace where were evaluated six local cultivars and a witness (plots) and six families of half sib progeny (subplots). The subplot was composed of six plants, a spacing of $3.0 \times 3.0 \mathrm{~m}$ [10] evaluated in three repetitions (18 total plants evaluated subplots), totaling 756 plants in the experiment. From the field test it was possible to estimate the variability between and within local varieties and families of half sib.

For the experiment was adopted the randomized block design with split plots where treatments were local cultivars sampled in five areas of family farming in the state 
(Novo Lugar, Novo Paraíso, São. Luís and São José, Benjamin Constant and Ilha da Paciência, Iranduba) and a commercial cultivar (Pumpkin Xingó Jacarezinho thick bark). Each local variety was obtained six families of half sib distributed subplots. The witness was used to cultivate Pumpkin Xingó Jacarezinho (open pollinated variety) and was assessed by sampling six subplots.

Three seeds were sowed in plastic cup $(180 \mathrm{ml})$ on May 27, 2013. Transplanting was done on the 6th of June. After the establishment of seedlings in the field, thinning was performed leaving only two plants per hole. It was calculated some values of: sanity loss index (SLI) and an occurrence severity scale of the disease caused by viruses (IV), quantified by symptoms expressing the presence of the pathogen and levels of damage to the plants.

The morphoagronomic descriptors lists were organized as follows: a. sheet size (petiole length, longitudinal limb length, transverse length); b. fruit weight (kg)-FrW; c. longitudinal length of the fruit $(\mathrm{cm})-\operatorname{LLFr}$; . cross fruit length $(\mathrm{cm})-C F r L$; e. longitudinal/transverse ratio of fruit-L/T RFr; $f$. number of wedges (unit)-NW; g. shell thickness $(\mathrm{mm})-\mathrm{ST}$; $\mathbf{h}$. pulp thickness $(\mathrm{cm})-\mathrm{PT}$; i. diameter of the internal cavity $(\mathrm{cm})-D C a v ; \mathbf{j}$. total number of fruit (unit)-TNFr; $\mathbf{k}$. total fruit weight $(\mathrm{kg})-\mathrm{TFrW} ; \mathbf{1}$. average fruit weight $(\mathrm{kg})-\mathrm{AFrW} ; \mathrm{m}$. average fruit weight $(\mathrm{kg}) / \mathrm{m}^{2}-\mathrm{AFrW} / \mathrm{m}^{2} ; \mathbf{n}$. fruit shape; o. main color of the peel (ripe fruit); p. presence of fruit buds; q. secondary buds; r. cross peduncle form; s. secondary color of the shell; t. color of the fruit pulp; $\mathbf{u}$. design produced by the secondary color of the shell; $\mathbf{v}$. bark texture [2].

It was held Variance Individual Analysis for each descriptor (feature) accessed to split plot [11]. The effects of plots and subplots were considered random and genetic component in the plot and environmental component in the error.

For the analysis of variance, the transformations were used [12]: petiole length (PL), the longitudinal length of the sheet (LLS), the total length of the sheet (TLS), transversal length leaf (TLL), fruit weight (FrW), longitudinal length of the fruit (LLFr), transverse length of the fruit (CFrL), longitudinal/transverse length ratio (L/T RFR), pulp thickness (PT), diameter cavity (DCav): $\mathrm{x}+0.5$; number of buds $(\mathrm{NW})$ and total number of fruit (TNFr): root $(\mathrm{x}+0.5)$; sanity loss index (SLI) and the occurrence of virose index (IV): $\operatorname{root}(\mathrm{x}+0.05)$.

Medium tests were applied Scott-Knott to the means of analysis of variance of experimental design of split plots and Dunnet to compare the means of local cultivars with the witness (commercial cultivar Xingó Jacarezinho thick bark) to $\mathrm{p}<0.05$ for characteristics with significant differences.

Genetic parameters of phenotypic variances were estimated- $\sigma_{\mathrm{f}} 1$ ), genotypic- $\sigma_{\mathrm{g}} 2$ ) and environmental- $\sigma_{\mathrm{A}} 3$ ), heritability- $h^{2} 4$ ), coefficient of variation- $\mathrm{CV}_{\mathrm{g}} 5$ ) and experimental- $\left.\mathrm{CV}_{\mathrm{e}} 6\right)$ genetic variance, phenotypic variance and environmental between and within plots [13].

Total phenotypic variance: $\hat{\sigma}_{F}^{2}=\hat{\sigma}_{d}^{2}+\hat{\sigma}_{e}^{2}+\hat{\sigma}_{g}^{2}$

Genotypic variance between treatment means: $\hat{\sigma}_{g}^{2}=(S T M-S E M) / r n$

Additive variance: $\hat{\sigma}_{A}^{2}=4 \hat{\sigma}_{g}^{2}$ 
Heritability: $\hat{h}^{2}=\frac{\hat{\sigma}_{g}^{2}}{(M S T / n r)}$

Genetic coefficient of variation: $C V_{g} \%=\left(100 \sqrt{\hat{\sigma}_{g}^{2}}\right) / \mathrm{m}$

Environmental coefficient of variation: $C V_{e} \%=(100 \sqrt{S E M / n}) / \mathrm{m}$

where $n$ is the number of plants per plot; $r$ is the number of replicates; MST is mean square of the treatments and $M S E$ is mean square error.

\section{Multivariate Analysis}

It used correspondence analysis to the characteristics of: fruit shape, the presence of buds, bark texture, color of the shell, the shell design and color of the pulp.

Based on the matrix consisting of the values of the variables mode: fruit shape, the presence of buds, the main color of the shell, the main design of the bark, bark texture and color of the flesh, there was a cluster analysis of the 36 families of means -brothers. For this, we used the method of grouping the average association, known by UPGMA (unweighted pair groups method) and the Mahalanobis distance as similarity measure [14].

\section{Results and Discussion}

The results of chemical analysis showed that the three areas of soil collection ( 3 blocks test) showed organic matter carbon content (C) considered good and an acidity ranging from low to more low. With respect to particle size, the results indicated sandy soil in Block 3, located on the terrace 3.

For the soil analysis data of particle size distribution and the degree of compression given to the sand content was higher in block three of the assay. Given this fact, some factors must be considered to understand the performance and development of local cultivars and witness. The major composition of the sand ground is strong contributor to higher water stress, low humidity for retention in macropores greater loss of nutrients and increased heating of the root system.

Moreover, observations obtained from experiments with vegetable showed that these differences in thickness of the surface sandy soil layer between terraces may, in addition to causing differences in the availability of water and nutrients to plants, may interfere with higher or lower incidence of disease.

The occurrence of disease may also be related to the loss of plant health. Plants with yellow leaf for environmental stress are susceptible to pathogen attack.

The records were collected for the period from 6/6/2013 to 16/9/2013, for the transplanting period for final location and stage of harvest of ripe fruit. The rains were more frequent in the range of 27 June to 11 July and the end of last month until the first half of August. The rainfall increased again in the first half of September. The mean rainfall for the period was $3.6 \mathrm{~mm} /$ day.

The temperatures ranged from $22.1^{\circ} \mathrm{C}$ to $35.5^{\circ} \mathrm{C}$ lower temperature and the highest temperature achieved in the above-day interval. The average value calculated for highest temperature was $32.9^{\circ} \mathrm{C}$ and $24.9^{\circ} \mathrm{C}$ for the lowest temperature recorded daily. 


\subsection{Quantitative Vegetative Descriptors}

The vegetative characteristics variance analysis sheet has not found significant contrasts between local cultivars, but detected at least a significant contrast to the $1 \%$ level of probability between subplots: petiole length, the longitudinal length of the sheet, transversal length of the sheet and the total sheet length (Table 1).

For fruit weight characteristics (FrW), longitudinal length of the fruit (LLFr), transverse length (CFrL), longitudinal/transverse length ratio (L/T RFr), shell thickness (ST), the data were significant for the subplots, demonstrating that at least one family of half-sibling is different in $1 \%$ level of significance. The LLFr characteristics, CFrL, L/T RFr, flesh thickness (PT) and cavity diameter (DCav) were significant in P $\mathrm{x} S$ interaction, which may indicate that among the cultivars there is a difference sites (Table 2).

The genetic divergence among pumpkins access is based on morphological characteristics. Nine descriptors were analyzed [15]. The results indicated a high degree of genetic variability, having no relationship between the collection site and the formation of the group of similarity. The greatest contribution of variables to genetic divergence was diameter greater fruit and fruit diameter of the inner cavity in longitudinal and latitudinal direction.

Works with several Cucurbitaceae were also developed by other authors [16], where the fruit morphological characteristics and seeds for some species were evaluated. The results showed that most variable characteristics are the shape, color and fruit size, and shape and seed size.

All data for the total number of fruit characteristics (TNFr), total weight of fruit (TFrW) and average fruit weight (AFrW) were significant, and at least one half sib progeny is different from the others. We can verify that local variation within cultivars is greater than the variation between local cultivars. This means that the half sib progeny are statistically different. The results for interaction Plots $(\mathrm{P}) \times$ Subplots $(\mathrm{S})$ were significant at the $5 \%$ level only for AFrW characteristic (Table 3 ).

Table 1. Variance analysis of morphological descriptors evaluated by vegetative characteristics of landraces Cucurbita maxima). Manaus, Amazon 2013.

\begin{tabular}{cccccc}
\hline \multirow{2}{*}{$\begin{array}{c}\text { Sources of } \\
\text { Variation }\end{array}$} & \multirow{2}{*}{$\begin{array}{c}\text { Degree of } \\
\text { Freedom }\end{array}$} & \multicolumn{4}{c}{ Average Square } \\
\cline { 3 - 5 } & & ${ }^{1} \mathrm{PL}$ & LLS & TLS & TLL \\
\hline Plot & 5 & $102.634 \mathrm{~ns}$ & $21.376 \mathrm{~ns}$ & $205.592 \mathrm{~ns}$ & $44.780 \mathrm{~ns}$ \\
Error a & 12 & 198.461 & 78.404 & 503.974 & 205.821 \\
Subplot a & 5 & $162.258^{* *}$ & $83.046^{* *}$ & $445.956^{* *}$ & $198.247^{* *}$ \\
Interaction PxS & 25 & $15.143 \mathrm{~ns}$ & $9.553 \mathrm{~ns}$ & $41.729 \mathrm{~ns}$ & $24.119 \mathrm{~ns}$ \\
Error b & 60 & 36.514 & 10.090 & 77.028 & 21.900 \\
Average & & 20.952 & 14.112 & 30.014 & 21.204 \\
${ }^{2}$ C.V. Plot\% & & 67.23 & 62.74 & 64.11 & 67.65 \\
${ }^{2}$ C.V. SubP\% & & 28.84 & 22.50 & 25.06 & 22.06 \\
\hline
\end{tabular}

${ }^{1}$ leaf petiole length PL: leaf petiole length $(\mathrm{cm})$; LLS: leaf longitudinal length $(\mathrm{cm})$; TLS: leaf total length, longitudinal axis $(\mathrm{cm})$; TLL: leaf transversal length comprimento $(\mathrm{cm}) ;{ }^{2}$ C.V.: (coefficient of variation); ${ }^{* *}$ : significant at $1 \%$ at $\mathrm{F}$ test. 
Table 2. Variance analysis of morphological descriptors evaluated by fruit biometrics in Cucurbita maxima local cultivars. Manaus, Amazon 2013.

\begin{tabular}{|c|c|c|c|c|c|c|c|c|c|}
\hline Sources of Variation & Degree of Freedom & \multicolumn{8}{|c|}{ Average Square } \\
\hline Plot & 5 & $0.218 \mathrm{~ns}$ & $56.459 \mathrm{~ns}$ & $18.434 \mathrm{~ns}$ & $0.750 \mathrm{~ns}$ & $0.095 \mathrm{~ns}$ & $0.379 \mathrm{~ns}$ & $8.556 \mathrm{~ns}$ & $0.135 \mathrm{~ns}$ \\
\hline Error a & 12 & 0.909 & 84.941 & 23.903 & 0.507 & 0.709 & 1.196 & 9.049 & 0.463 \\
\hline Subplot & 5 & $1.443^{\star \star}$ & $379.182^{\star *}$ & $58.665^{\star \star}$ & $4.132^{* \star}$ & $0.290^{* *}$ & $0.999 \mathrm{~ns}$ & $22.125 \mathrm{~ns}$ & $0.162 \mathrm{~ns}$ \\
\hline Error b & 60 & 0.130 & 25.089 & 6.715 & 0.284 & 0.130 & 0.329 & 4.429 & 0.292 \\
\hline Average & & 1.241 & 17.70113 & 12.162 & 1.590 & 0.806 & 2.308 & 7.807 & 2.138 \\
\hline${ }^{2}$ C.V.Plot $\%$ & & 76.85 & 52.06 & 40.19 & 44.798 & 104.42 & 47.37 & 38.53 & 31.82 \\
\hline${ }^{2}$ C.V. SubP\% & & 29.09 & 28.20 & 21.30 & 33.559 & 44.70 & 24.84 & 26.95 & 25.26 \\
\hline
\end{tabular}

${ }^{1} \mathrm{FrW}$ : fruit weight $(\mathrm{kg})$; LLFr: fruit longitudinal length (cm); CFrL: fruit transversal length (cm); L/T RFr: ratio fruit longitudinal length/transversal (cm); ST: fruit skinl thickness (mm); PT: fruit pulp thickness (cm); DCav: cavity diameter result in cross-section (cm); NW: number of ribs (unit); ${ }^{2}$ C.V.: Coefficient of Variation); $* * * *$ : significant at 1 and $5 \%$ at $\mathrm{F}$ test.

Table 3. Variance analysis of fruit agronomic characters evaluated in Cucurbita maxima local cultivars. Manaus, Amazon. 2013.

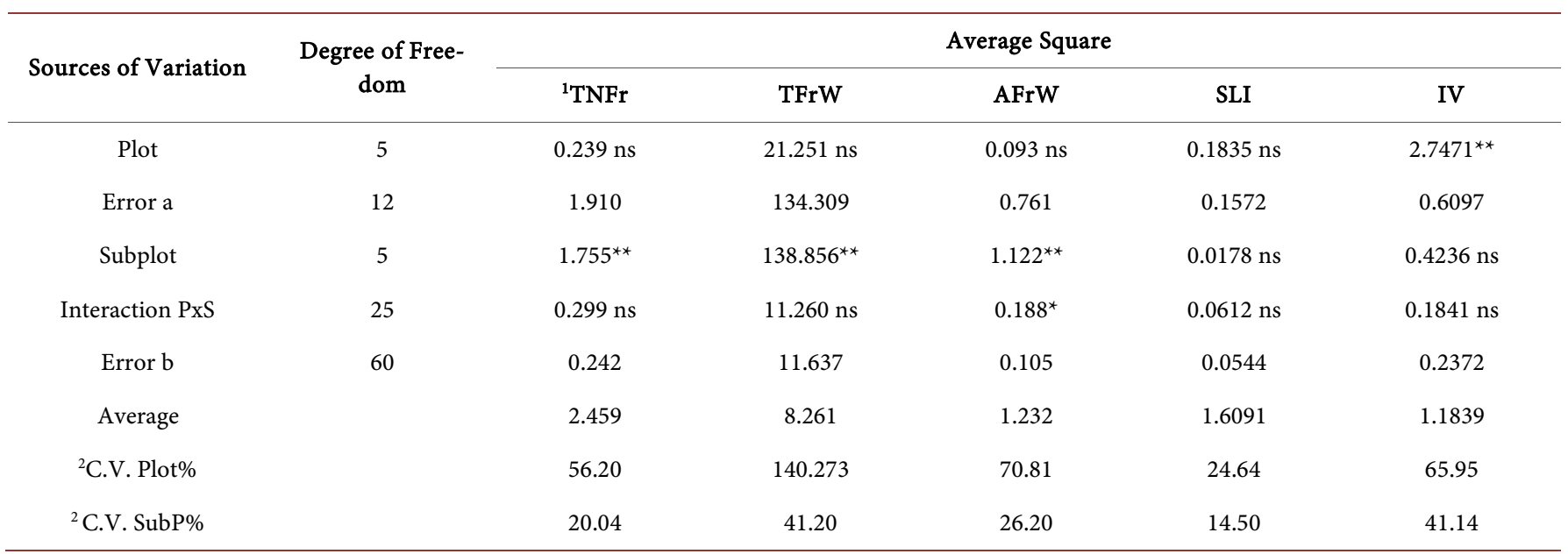

${ }^{1} \mathrm{TNFr}$ : total number of fruit (unit.); TFrW: total weight of fruit (kg); AFrW: average fruit weight (kg); SLI: loss sanity index; IV: occurrence of virus index; ${ }^{2} \mathrm{C} . \mathrm{V}$.: Coefficient of Variation; ${ }^{* * *}$ : Significant at 1 and $5 \%$ at $\mathrm{F}$ test.

The featuring 36 native populations of cultured pumpkins $C$. moschata and C. argyrosperma was made and it was found that the variability can be explained based on specific uses regional fruits and seeds [17]. Quantitative characteristics that explain part of the variation found were: width of the fruit pulp, width and length of the fruit; width, length and weight of 100 seeds, and, days of female flowering. The variability is attributed to seed selection criteria made by farmers and housewives, house and the cross-pollination nature of the species with pollinated by bees. Both forms of use such as the management practices have allowed the genetic variation of $C$. moschata is conserved and is a continuous source of variability [17].

Further research also contributed to characterize the variability of the Cucurbita ge- 
nus, in order to discriminate material collected at fairs, markets, family farming and access of Banks Germplasm (BAGs) national research institutions. In the estimation of phenotypic, genotypic and environmental correlations for seven morphological characteristics seven pumpkin accesses (C. maxima) found that the genetic correlations were higher than the phenotypic and environmental, indicating moderate influence of the latter in the expression of the characters [18]. Sixty-five BAG Cucurbita accesses have been characterized morphologically by suitable descriptors, those recommended by the International Plant Genetics Resources Institute [19].

Highlighted the need for morphological characterization activities, through the use of a descriptive list provides further information about the germplasm maintained [10].

A study was conducted to estimate the genetic divergence in 16 pumpkin accessions of the Embrapa Semi-Arid Germplasm Bank of Cucurbitaceae, based on morphological and agronomic characterization to guide breeding work with the species. The material investigated was found high genetic variability, where the variables that provided greater contribution to determine the genetic divergence were: larger diameter and fruit diameter of the inner cavity of the longitudinal and latitudinal fruit [15].

\subsection{Qualitative Characteristics}

The Correspondence Analysis pointed to two main axes to explain the variation between samples collected for the qualitative characteristics: a. fruit shape; b. main color of the shell; c. secondary buds; $d$. color of the fruit pulp; e. design produced by the secondary color of the shell; f. bark texture.

The quality characteristics by Correspondence Analysis and observed that the qualitative variation was explained by the leaves characteristics, the fruit shape and intensity leaf mottle [14] [17]. Pumpkin species C. argyrosperma, the Yucatan Peninsula, Mexico, were analyzed 37 qualitative characteristics. Those that stood out for showing greater variation were tertiary fruit color intensity of the spots of the leaves, border color and seed coat and shape of the edge of the sheet allowing the formation of seven species groups [14].

The dendrogram generated from the qualitative characteristics with a cut line in 0.9, the Mahalanobis distance, generated three main groups, bringing together more families of half-sib progeny (Figure 2). The cophenetic correlation coefficient (0.951) showed adequacy of the algorithm used. Group 1 housed the families of half-sib progeny, NP2, NP4, NP6, SL3, IA1 and IB4 presenting fruits of elliptic and globular shape, the presence of buds of intermediate type and main color of light and dark green rind.

The second and larger group convened by dendrogram housed most families of half-sib progeny by fruit flattened and elongated shape, with superficial buds and main skin color ranging from green light to dark. Group 3 consists of half-sib families NL3, NL5, SJ1, SJ2, SJ3 and IB2, IB5, IB 6, with varying formats fruit of elliptical type, cordate, elongated and flattened, with the presence of deep buds and light green color. The families of half-brothers and IB1 NL6 were considered similar and the ones that had white fruit, superficial bud and elongated shape. 


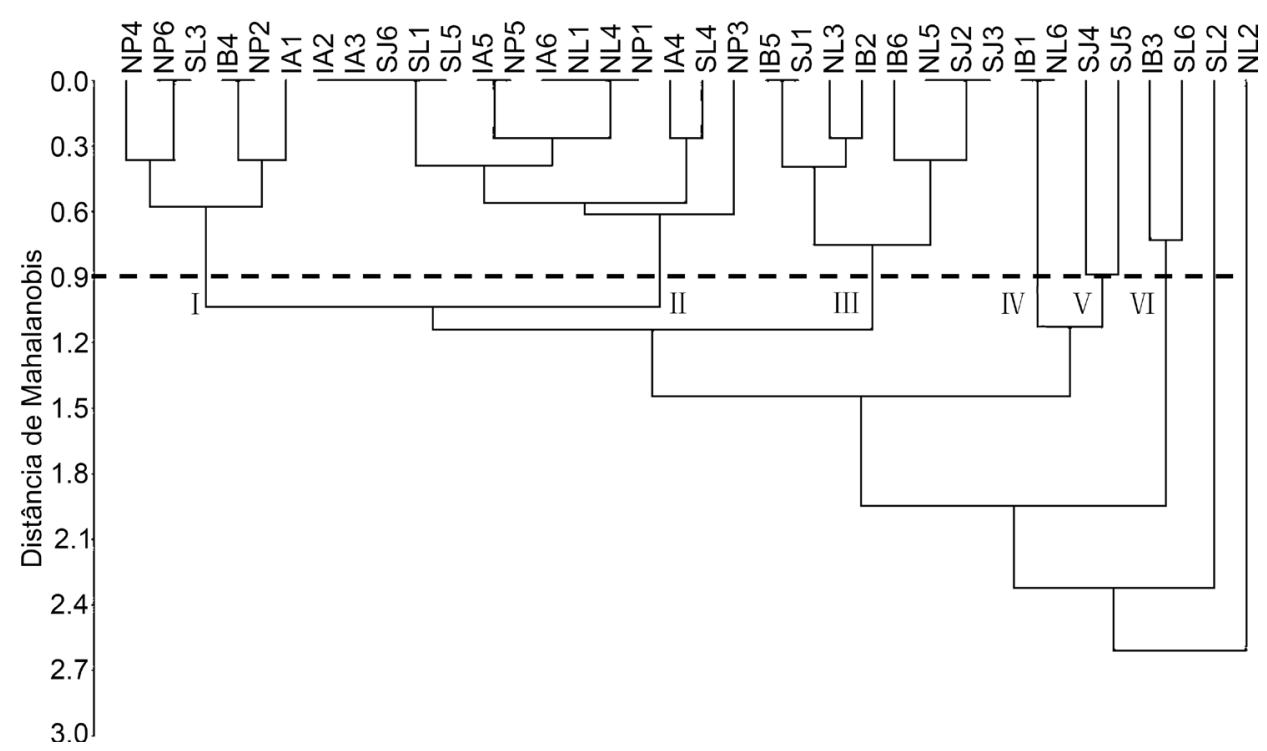

Figure 2. Genetic dendrogram of similarity among 36 samples pumpkin landraces (Cucurbita maxima), obtained by the UPGMA method based on Mahalanobis Distance from six qualitative characters. Manaus, Amazon. 2013.

From the dendrogram conformation of results, you can see that the qualitative morphological characteristics are responsible for gathering half-sib progeny collected in geographically distant locations, located in the Upper and Lower Solimões region. In all generated groups, families Iranduba A and B were present together with the half-sib progeny sampled in Benjamin Constant. In the molecular analysis with the same samples it can observe the formation of six groups that coincide with local cultivars separated by geographical distances [20]. In molecular studies is possible to observe different results compared with morphoagronomical tests. We can conclude that forms of cultivation and management adopted by farmers maintain the identities of local cultivars and at the same time, the diversity of levels for macroenvironmental adaptability guarantee.

The consequence of the narrowing of the genetic base and the use of uniform genotypes in large areas can lead to the risk of extinction of species, for these become much more susceptible to competition, disease, climate change, among others [21].

\subsection{Genetic Parameters}

Genetic parameters were estimated: genetic, phenotypic and environmental variance among and within local cultivars, genetic variation coefficient and heritability [13].

Observed high values for heritability parameter $\left(\mathrm{h}^{2}\right)$ above $90 \%$ for the longitudinal length characteristics of the fruit (LLFr), transverse length of the fruit (CFrL), pulp thickness (PT) and diameter of the cavity in cross-section (DCav) were high indicating that these characteristics can be passed to the next generation (Table 4). Heritability was considered high for the characteristics total weight of the fruit (TFrW) and average fruit weight (AFrW) with values above $70 \%$. The characteristic total number of fruit presented very low as an indication that the genetic component has little influence 
Table 4. Estimates variance of phenotypic $\left(\sigma_{f}^{2}\right)$, genotypic $\left(\sigma_{g}^{2}\right)$ and environmental $\left(\sigma^{2}\right)$, the heritability $\left(\mathrm{h}^{2}\right)$, the genetic variation coefficients $\left(\mathrm{CV}_{\mathrm{g}}\right)$ and experimental $\left(\mathrm{CV}_{\mathrm{e}}\right)$ for agronomic characteristics of Cucurbita maxima local cultivars. Manaus, Amazon. 2013.

\begin{tabular}{ccccccc}
\hline${ }^{1}$ Characteristcs & $\sigma_{f}^{2}$ & $\sigma_{g}^{2}$ & $\sigma^{2}$ & $\mathbf{h}^{2}(\%)$ & $\mathrm{CV}_{\mathrm{g}}$ & $\mathrm{CV}_{\mathrm{e}}$ \\
\hline LLFr & 38.4649 & 18.4261 & 20.0388 & 94.87 & 22.50 & 9.06 \\
CFrL & 5.4238 & 2.5695 & 2.8543 & 94.70 & 13.22 & 5.42 \\
PT & 0.1869 & 0.0744 & 0.1125 & 92.37 & 11.86 & 5.91 \\
DCav & 2.8487 & 1.2883 & 1.5604 & 94.50 & 14.53 & 6.07 \\
TNFr & 0.3256 & 0.2160 & 0.1096 & 38.30 & 6.08 & 13.36 \\
TFrW & 19.4094 & 3.6867 & 15.7227 & 72.57 & 24.08 & 25.64 \\
AFrW & 0.1837 & 0.0592 & 0.1245 & 78.52 & 20.87 & 18.91 \\
\hline
\end{tabular}

${ }^{1}$ LLFr: fruit longitudinal lengtn (cm); CFrL: fruit transversal length (cm); PT: pulp thickness (cm); TNFr: total number of fruit; TFrW: total weight of fruit $(\mathrm{kg})$; AFrW: average fruit weight $(\mathrm{kg})$.

on this feature.

It was found high heritability values also for the characteristics average fruit weight, external longitudinal length and thickness of the pulp, all above 70\% [22]. Some scientific paper found high heritability for some characteristics that match the high levels of C. maxima of this Cucurbita study (cultivars, a hybrid and an improved genotype) [23]. The characteristics exhibited high heritability were fruit length ( $h^{2}=98$ and 97\%), fruit width $\left(h^{2}=98\right.$ and $\left.95 \%\right)$, pulp thickness $\left(h^{2}=98\right.$ and $96 \%$ in three regions of the fruit) and height the result of the internal cavity $\left(h^{2}=99\right.$ and $\left.97 \%\right)$, and the first and second year, respectively.

\section{Conclusions}

1. This study revealed that there is significant contrast in the level of $1 \%$ probability among the subplots (half sib progeny) for PL, LLS, TLS, TLL and FrW, LLFr, CFrL, L/T RFr and ST.

2. All data for TNFr, TFrW and AFrW are significant, and at least one half sib progeny is different from the others.

3. The variation within local cultivars is greater than the variation among local cultivars.

4. The qualitative morphological characteristics bring together half-sib families collected in geographically distant locations, located in the Upper region and Lower Solimões, Amazonas.

5. It can be concluded that, through the estimation of genetic parameters, there is genetic variability among local cultivars collected in family farming of Benjamin Constant (Upper Solimões) and Iranduba (Lower Solimões), Amazonas.

\section{Acknowledgements}

On the Coordination Education CAPES, CNPq Project Process 403819/2013-0 Seeds and Agroecological technologies for Family Agriculture in the Amazonas and MecSesu 
Project/UFAM Advisory Participative the Young Family Farmers in the Upper Solimões River Region for financial support of the research.

\section{References}

[1] Lopes, J.F. and Menezes Sobrinho, J.A.De (1998) Germplasm Collection Pumpkin and Squash. EMBRAPA-CNPH, Brasília.

[2] Esquinas-Alcazar, J.T. and Gulick, P.J. (1983) Genetic Resources of Cucurbitaceae. IPBGR, Rome.

[3] Saade, R.L. and Hernández, S.M. (1992) La Agricultura em Mesoamerica: Cucurbitas. In: Hernández Bermejo, J.E. and Léon, J., Eds., Marginalized Crops. Another Perspective of 1492, No. 26, Collection FAO Plant Production and Protection, Rome.

[4] Lima, G.K.L. (2013) Rescue and Study Germplasm of Cucurbita spp. Rio Grande do Norte. Doctoral Thesis, Mossoro.

[5] Ramos, S.R.R., De Queiroz, M.A., Meirelles, A.C.S. and Da Ferreira, M.A.J. (2007) Survey in Situ Conservation Status and Areas of Occurrence of Local Cultivars of Cucurbita sp. in Ceara. In: Brazilian Vegetable Crops Congress, Brazilian Symposium on Cucurbitaceae, Rescues and Underused Vegetable, Brazilian Association of Horticulture, Porto Seguro, 4 p.

[6] Heiden, G., Barbieri, R.L. and Neitzke, R.S. (2007) Key to the Identification of Species of Pumpkins (Cucurbita, Cucurbitaceae) Grown in Brazil. Documents 197, Embrapa Clima Temperado, Pelotas.

[7] Sioli, H. (1991) Amazon. Ecology Fundamentals of the Largest Region of Tropical Forests. 3rd Edition, Vozes, Petrópolis.

[8] Vencovsky, R. (1987) Effective Population Size in the Collection and Preservation of Germplasm Outcrossing Species. Journal of the Institute of Research and Forest Studies, 35, 79-84.

[9] Marques, C.M.M., Silva Filho, D.F., Paiva, J.L., Soares, J.E.C., Noda, H., Machado, F.M. and Batista, M.RA. (2013) Agronomic and Nutritional Potential Aria Clones (Calathea allouia (Aubl.) Lindl) Evaluated in Manaus, Amazon. In: Noda, H., Souza, L.A.G. and Silva Filho, D. F., Eds., Family Agriculture in the Amazon, Wega, Manaus, 71-86.

[10] Ramos, S.R.R., Queiróz, M.A., Casali V.W.D. and Cruz, C.D. (1999) Cucurbita moschata Genetic Resources: Morphological Characterization of Local Populations Collected in the Brazilian Northeast. In: Queiróz, M.A., Goedert, C.O. and Ramos, S.R.R., Eds., Genetic Resources and Plant Breeding for the Brazilian Northeast, Version 1.0. Embrapa Semi-Árido e Embrapa Genetic Resources and Biotechnology, Brasília. http://www.cpatsa.embrapa.br/catalogo/livrorg/abobora.pdf

[11] Cruz, C.D. (2006) Genes Program: Experimental Statistical and Matrices. UFV, Viçosa.

[12] Steel, R.G.D. and Torrie, J.H. (1960) Principles and Procedures of Statistic with Special Reference to the Biological Sciences. McGraw-Hill, New York.

[13] Vencovsky, R. and Barriga, P. (1992) Genetics Biometrics in Plant Breeding. Brazilian Society of Genetics, Ribeirão Preto.

[14] Rodriguez-Amaya, R., Montes-Hernadez, S., Rangel-Luio, J.A., Mendoza-Elos, M. and Latournerie-Moreno, L. (2009) Morphological Characterization of Pipiana Squash (Cucurbita argyrosperma Huber). Agricultura Técnica En México, 35, 378-388.

[15] Borges, R.M.E., de Lima, M.A.C., Ramos, S.R.R., Gonçalves, E.S.A., de Alencar, O.G., Landim, C.S. and Silva, U.A. (2011) Genetic Diversity among Pumpkin Access Based on Morphoagronomic Characteristics. 1 st Meeting of Biofortification, Teresina, 5 p. 
[16] Delgado-Paredes, G.E., Rojas-Idrogo, C., Sencie-Tarazona, A. and Vásquez-Núnez, L. (2014) Characterization of Fruits and Seeds of Some Cucurbitaceae in Northern Peru. Revista Fitotecnia Mexicana, 37, 7-20.

[17] Canul KU, J., Vallejo, P.R., González, F.C. and Servia, J.L.C. (2005) Morphological Diversity of Pumpkin Grown in the Central-Eastern Yucatan, Mexico. Revista Fitotecnia Mexicana, 28, 339-349.

[18] Amaral JR, A.T., Casali, V.W.D., Finger, F.L., Cruz, C.D. and Silva, L.F.C. (1996) The Morphoagronomic Variability and Isozyme between Access of Pumpkin (Cucurbita maxima Duch). Revista Ceres, 43, 581-590.

[19] Barbieri, R.L., Heiden, G., Neitzke, R.S., Garrastazú, M.C. and Schwengber, J.E. (2006) Germoplasm Bank Active of Cucurbit Embrapa Temperate Climate: From 2002 to 2006. Documents 176, Embrapa Clima Temperado, Pelotas.

[20] Martins, L.H.P. (2015) Variability Genetics and Cucurbita maxima Conservation Duchesne Family Agriculture in the Amazon Western Central. Doctoral Thesis, Universidade Federal do Amazonas, Manaus.

[21] Nass, L.L. and Sigrist, M.S. (2009) Wild Species: Exploration Potential in the Pre-Breeding. In: Borém, A., Lopes, M.T.G. and Clement, C.R., Eds., Domestication and Breeding: Amazonian Species, Universidade Federal de Viçosa, Viçosa, 101-116.

[22] Bezerra Neto, F.V., Leal, N.R., Costa, F.R., Gonçalves, G.M., Amaral Júnior, A.T., Vasconcellos, H.O. and Mello, M. (2006) Biometric Analysis of Squash Lines. Horticulture Brazilian, 24, 378-380.

[23] Blank, A.F., Silva, T.B., Matos, M.L., Carvalho Filho, J.L.S. and Silva-Mann, R. (2013) Genotypic, Phenotypic and Environmental Parameters for Morphological and Agronomic Characters of Pumpkin. Horticulture Brazilian, 31, 106-111.

https://doi.org/10.1590/S0102-05362013000100017

Submit or recommend next manuscript to SCIRP and we will provide best service for you:

Accepting pre-submission inquiries through Email, Facebook, LinkedIn, Twitter, etc.

A wide selection of journals (inclusive of 9 subjects, more than 200 journals)

Providing 24-hour high-quality service

User-friendly online submission system

Fair and swift peer-review system

Efficient typesetting and proofreading procedure

Display of the result of downloads and visits, as well as the number of cited articles

Maximum dissemination of your research work

Submit your manuscript at: http://papersubmission.scirp.org/

Or contact as@scirp.org 